\title{
Determination of shelf life of Yellowfin tuna (Thunnus albacares) with regard to microbial count, histamine level and flesh colour
}

\author{
L. H. D. Hansamali ${ }^{1}$, R. R. M. K. P. Ranatunga ${ }^{1 *}$, P. K. C. Buddhinie ${ }^{2}$ and P. Ashoka ${ }^{3}$ \\ ${ }^{1}$ Centre for Marine Science and Technology, Department of Zoology, University of \\ Sri Jayewardenepura \\ ${ }^{2}$ Department of Botany, University of Sri Jayewardenepura, Nugegoda, Sri Lanka \\ ${ }^{3}$ Jay Sea Foods Processing (Pvt.) Ltd, Ja-Ela, Sri Lanka
}

*Correspondence (ranatunga@sci.sjp.ac.lk)

https://orcid.org/0000-0002-0432-6003

Received: 02.07.2019 Revised: 28.09.2019 Accepted: 03.10.2019 Published online: 21.03.2020

\begin{abstract}
Yellowfin tuna (YFT) (Thunnus albacares) is among the most popular fish in seafood trade all over the world. The quality of tuna meat is the main determinant of its market price. This study was conducted to determine the shelf life of YFT flesh stored at $0-2^{\circ} \mathrm{C}$ in terms of microbial total plate count (TPC), histamine levels and flesh colour change within 15 days of storage. Twenty-five YFT samples collected from a seafood processing factory, on the same day they received from the multi-day boats, were used in the study. In each visit, five fish samples were collected with the same catching date (5 days before landing). Samples were vacuum packed and taken to the laboratory where they stored under $0-2^{\circ} \mathrm{C}$. All experiments were conducted on 1st, 4th, 7th, 11th, 14th and 15th days of storage. Pour plate method was conducted for total microbial plate count. Histamine content was determined using competitive ELISA method. Flesh colour change was determined by calculating the value of Red, Green, and Blue (RGB) colour ratios of the images using a colour detector mobile application. Results showed that the highest microbial count was exhibited on 7th day of storage and did not exceed more than $10^{5} \mathrm{CFUg}$ 1. Histamine levels were increased up to a maximum mean value of $14.24 \mathrm{ppm}$ during the storage. Microbial counts and histamine results suggest that it is safe to consume YFT within 15 days under $0-2^{\circ} \mathrm{C}$ storage conditions.
\end{abstract}

Keywords: Yellowfin tuna, shelf life, histamine level, microbial count, flesh colour

\section{INTRODUCTION}

Yellowfin tuna (YFT) (Thunnus albacares) is a marine large pelagic fish belong to family Scombridae. The YFT is one of the most important commercially traded species in the world. The YFT are exported frozen and the highest quality fish ended up in sashimi trade (Jinadasa et al. 2015). Higher prices are offered in this highly competitive and demanding sashimi trade in Japan. YFT is popular in both local and export markets of Sri Lanka and YFT is the most sought-after commercial tuna species and one of the largest exporters of tuna as well as one of the oldest tuna processing countries in the Indian ocean (Agustini et al. 2001, Jinadasa et al. 2015). In the local market, it is mostly price-oriented with low emphasis on quality of YFT.

Freshness is an extremely important factor that determines the overall quality of a particular fish product. YFT is an important source of protein, however, can cause severe issues in end users mainly due to histamine food poisoning (Kim et al. 2005) which is an important fish food born disease all over the world (Olsen et al. 2000). Histamine or scombrotoxin is a biogenic amine produced as a result of time and temperature abuse. Further, bacterial species producing enzyme histidine decarboxylase is capable of converting histidine in fish into histamine (Lehane et al. 2000). This histidine decarboxylase producing bacteria grow in a wide range of temperature. Thus; histamine may result even with the low temperatures (Visciano et al. 2014).

These decarboxylase producing bacteria are commonly found in gills, external surface in the fish gut without harm to the fish. However, after harvesting, processes such as filleting may increase the risk of contamination of fish flesh with those microorganisms and this will lead to histamine production in the flesh up to toxic levels. Microbial contamination causes fish spoilage as well. Bacteria in the gills, gut, and skin begin to metabolize surrounding low- 
molecular-weight compounds and produce volatile compounds that cause the spoilage. Also, there is a direct relationship between the total numbers of microorganisms and the degree of spoilage (Gram and Huss 1996).

Previous studies by Wei et al. (1990), Kim et al. (2004) and Jinadasa et al. (2015), have shown the factors leading to the deterioration of fish quality and techniques that used to extend the shelf life of fish. Fish quality deterioration occurs rapidly during handling and storage; (Guizani et al. 2005) hence limits the shelf life. The shelf life is the period of time under storage which retains its desired sensory, chemical, physical, functional, or microbial characteristics (Gray et al. 1996). Jinadasa et al. (2015), has shown that the shelf life of YFT limits for 14 days of storage under $<4^{\circ} \mathrm{C}$ storage condition when vacuum packed.

Colour is a visual indicator used in assessing the quality of fish and different grades are allocated based on the colour. Having a colour change assessment chart in the grading process would helpful in more accurate and easier identification of fish quality. Flesh colour change can be determined by colour analyser software which use Red, Green, and Blue (RGB) colour ratios in a given photograph to construct colour charts that will help to categorize the fish into grades easily without confusions. (Odrowaz 2019.)

In this study, the major objectives were to identify whether the shelf life of YFT could be extended under $0-2{ }^{\circ} \mathrm{C}$ storage temperatures by monitoring the microbial counts, and histamine levels. Further, an attempt was made to analyse the fish flesh colour change using RGB detection mobile application.

\section{MATERIALS AND METHODS}

YFT samples were collected from a seafood processing and exporting company. In each visit, five fish samples were collected among the grade A quality fish in the processing. All the fish samples derived from a section taken close to the middle part of the body away from the spinal bone. Twenty-five YFT samples were collected through the study over five visits. Care was taken to collect the fish with same catching date (5 days before landing). Fish samples were vacuumpacked and kept in ice, and brought to the microbiology laboratory of the Department of Botany in University of Sri Jayewardenepura within four hours and stored under $0-2^{\circ} \mathrm{C}$ in a deep-freezer (same storage conditions as in the commercial storage of the exporting company).

The analysis was started on the following day considering as day 1 . In day 1 , microbial test, histamine test and photographs of fish flesh for image analysis were taken for preparing colour chart. The procedure was repeated at days 4,7 , 11,14 , and 15 of storage.

\section{Determination of Total Plate Count (TPC)}

A piece of one gram (1g) was cut aseptically from the YFT fillet and crushed using a motor and pestle. $10 \mathrm{ml}$ of sterile distilled water was added to the homogenized flesh and mixed them thoroughly. Ten-fold dilutions were prepared up to $10^{-3} \mathrm{~mol} \mathrm{dm}^{-3}$ and $1 \mathrm{ml}$ each dilution was inoculated in pour plates using nutrient agar medium. Colony forming units $\left(\mathrm{CFUg}^{-1}\right)$ were determined after incubation for one day (24 hours) at $37^{\circ} \mathrm{C}$.

\section{Determination of histamine concentration of YFT flesh}

Histamine concentration was determined using competitive ELISA method. The YFT samples were blended and $10 \mathrm{~g}$ of each YFT sample was added to bottles containing $90 \mathrm{ml}$ of distilled water. Bottles were shaken vigorously to suspend for 15-20 seconds and waited for 5 minutes to prepare suspension (this step was triplicated). 10 $\mathrm{ml}$ of sample extract diluent buffer was added to a clean test tube. Aliquots of $100 \mu 1$ of YFT extract was added to the sample extract buffer and swirled to mix gently.

Veratox ${ }^{\circledR}$ histamine tuna pack was used to determine the histamine level of YFT. There are two types of wells in this tuna pack. The redmarked wells are mixing wells and white colour wells are antibody-coated wells. $100 \mu \mathrm{l}$ of the conjugate was added to red-marked mixing well strips. Then $100 \mu \mathrm{l}$ of controls (bottles containing $0,2.5,5,10,20$ and $50 \mathrm{ppm}$ histamine concentration) and diluted samples were transferred to the red-marked mixing wells. The content was mixed by pipetting up and down three times. $100 \mu \mathrm{l}$ of the above mixture was transferred into the antibody-coated microwells and incubated for 10 minutes at room temperature $\left(18-30^{\circ} \mathrm{C}\right)$ mixing for the first $10-20$ seconds by sliding the microwell holder back and forth on a flat surface without splashing the reagents from the wells. Red-marked mixing 
wells were discarded and shacked the contents of antibody wells.

Each antibody wells were filled with diluted wash buffer (concentrate of $10 \mathrm{mmoldm}^{-3}$ PBSTween) and dumped them out (this step was triplicated). Then the wells were turned upside down and tapped out remaining liquid on an absorbent towel. Aliquots of $100 \mu \mathrm{l}$ of $\mathrm{K}$ Blue ${ }^{\circledR}$ substrate solution was pipetted into wells and incubated for 10 minutes at room temperature $\left(18-30^{\circ} \mathrm{C}\right)$ mixing for the first $10-20$ seconds by sliding back and forth on a flat surface. The remaining substrate was discarded, and wells were rinsed with water. The same pipette tips on the 12-channel pipette were used to dispense substrate. $100 \mu \mathrm{l}$ of Red stop was added to each well and mixed by sliding back and forth on a flat surface. The results were read in a microwell reader at $650 \mathrm{~nm}$ wavelength. Results were obtained within 20 minutes of completion of the test.

\section{Colour change}

In each sampling analysis day (1st, 4th, 7th, 11th, 14th, 15th day of storage) photographs of YFT fillets were obtained using a HTC 728 desire smartphone with a back camera with 15 megapixel resolution. The red value of each photograph was detected using RGB (Red Green Blue) colour analyser and red colour values were compared within storage duration (Mateo et al. 2006). For the standardization of sampling technique, the photographs were obtained in the same time of the day, the same distance from the object and under the same illumination conditions.

\section{Statistical analysis}

Statistical analysis was conducted using Minitab 2017. One-way analysis of variance (ANOVA) was carried out to analyse results obtained for histamine concentration, total plate count and red values of YFT flesh were compared using Tukey's pairwise comparison.

\section{RESULTS}

\section{Total plate count}

It was observed that the initial suspension $(1 \mathrm{~g}$ of fish sample dissolved in $10 \mathrm{ml}$ of sterile distilled water) was more crowded and colonies were not regularly presented in $10^{-2}$ and $10^{-3}$ moldm $^{-3}$ dilution of YFT flesh. Therefore, $10^{-1}$ was used as the best dilution to obtain microbial colony counts. The changes in mean TPC values within 15 days of storage is shown in figure 1.

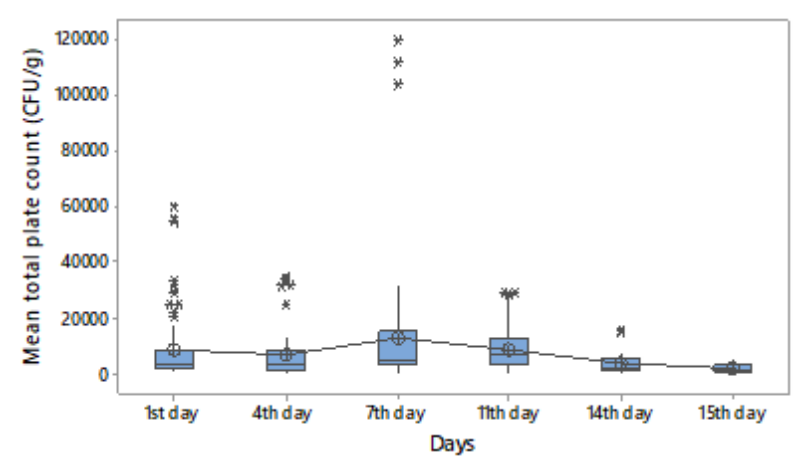

Fig 1 The change of mean TPC values of YFT at $0-2^{\circ} \mathrm{C}$ condition over 15 days. $(*$ represent the outliers)

According to Tukey's pairwise comparisons of one-way ANOVA test $(\alpha \leq 0.05, \mathrm{P}$ value $=0.0)$, the highest TPC number $\left(1.29 \times 10^{4} \mathrm{CFUg}^{-1}\right)$ recorded in day 7 and lowest TPC number $\left(1.94 \times 10^{3} \mathrm{CFUg}^{-1}\right)$ records in day 15 . Initial microbial colony count (day 1 ), $8.8 \times 10^{3} \mathrm{CFUg}^{-1}$ is higher than the last day of storage (day 15), $1.29 \times 10^{4} \mathrm{CFUg}^{-1}$. When considering the whole change of TPC has increased from day 1 to day 7 and decreased from day 7 to day 15 . Within the storage period at $0-2^{\circ} \mathrm{C}$, TPC number did not exceed $10^{5} \mathrm{CFUg}^{-1}$ European standard value (EU/EC, 2005), which is followed by the export company.

\section{Histamine levels}

The change of Histamine concentration of YFT stored at $0-2^{\circ} \mathrm{C}$ over 15 days is shown in figure 2 . Mean histamine concentrations were increased within the storage duration.

According to histamine levels, day 15 records the highest mean histamine concentration, $14.24 \mathrm{ppm}$ and day 7 records the lowest mean histamine concentration, $2.104 \mathrm{ppm}$. Under $0.05 \%$ significant level $(\mathrm{P}=0.08)$, there is no significant difference in mean histamine concentrations on day 1 , day 4, day 11 and day 14 of storage. There is no significant increase in histamine concentration from day 1 to day 7 of storage and there is a significant increase in histamine concentration day 7 to day 15 of storage. 


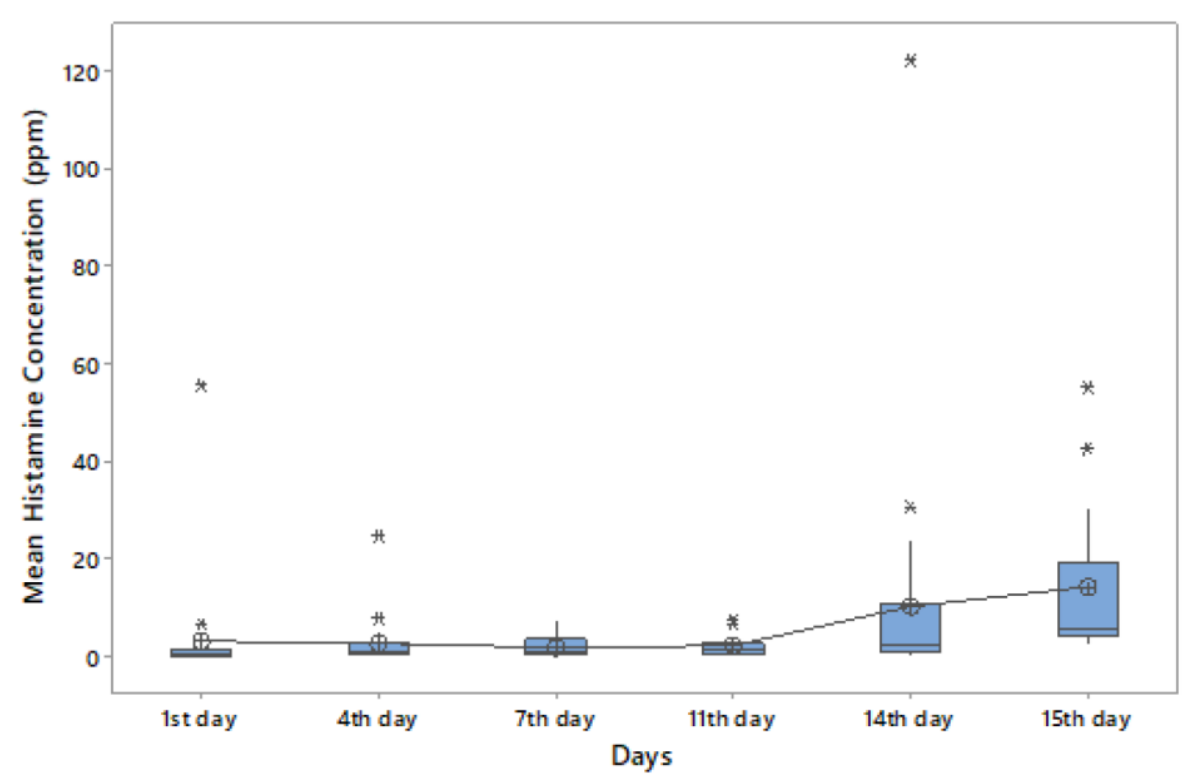

Fig 2 The change of Histamine concentration (ppm) of YFT stored at $0-2^{0} \mathrm{C}$ over 15 days. (* represent the outliers)

According to Jinadasa et al. (2015), the temperature has a strong effect of histamine formation and histamine form very quickly in YFT stored at $7^{\circ} \mathrm{C}$ and it has reached up to $136 \pm$ $25 \mathrm{mg} / \mathrm{kg}$ in 21 days, but the gradual increase has been observed after day 5 and found that histamine production can be controlled when the temperature is maintained around $0^{\circ} \mathrm{C}$ or below $4^{\circ} \mathrm{C}$.

According to the results, the highest histamine concentration (14.24 ppm) within 15 days of storage was not exceeded $20 \mathrm{ppm}$ European standard. It can be concluded that. Generally, histamine concentration is high close to fish bones and low in the other areas of the body. Because it takes more time for colder temperature to reach deeper muscles.

Baranowski et al. (1990) observed that the duration of freezing of fish is an important factor for histamine formation during storage. According to Price et al. (1991) histamine formation inhibit at $0^{\circ} \mathrm{C}$ or below, but histamine production could continue due to pre-existing histidine decarboxylase. It could be one of reasons for increasing histamine during the storage.

\section{Colour change}

The change of mean red values of the RGB spectrum within 15 days of storage is shown in Figure 3 and Change of YFT flesh colour within 15 days of storage at $0-2^{\circ} \mathrm{C}$ is shown in figure 4 . The red values showed an exponential decrease at the beginning; however, slower change towards the end within 15-days storage duration. 


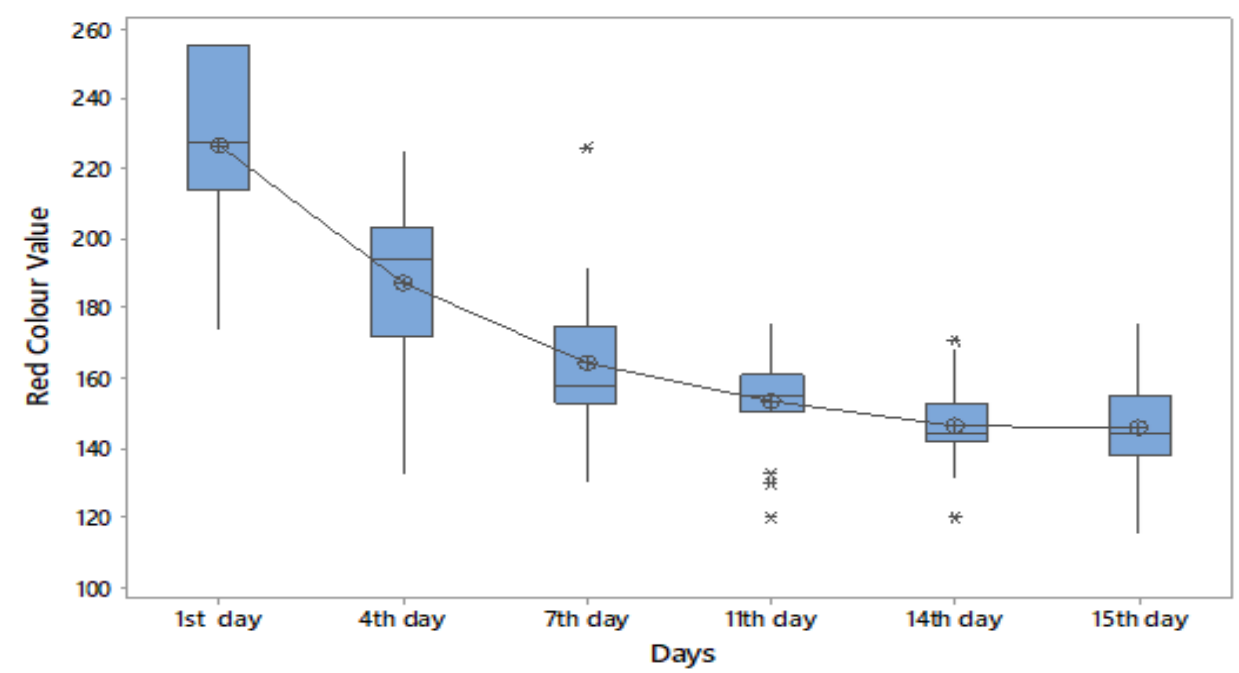

Fig 3 Changes of the red value of YFT flesh within 15 days of storage which was taken from RGB, colour analysis.

According to Tukey's pair-wise comparisons in one-way ANOVA test, day 1 records the highest mean red value (226.87) but reduced with time. Under 0.05 significant level, day 4 red value is 187.13 and day 7 red value is 164.40 . There is a significant difference in day 1 to day 4 red value and day 4 to day 7 red values. But day 7 to day 11 , day 11 to day 14 and day 14 to day 15 were not significantly different. The highest red value was shown on day 1 and it was decreased significantly till day 7 . After day 7 the red value was not significantly changed. Hence there was no significant difference in red value between day 7 to day 15 .

In this study, the YFT were stored in vacuum packs with maintaining the temperature at $0-2^{\circ} \mathrm{C}$. The effect of vacuum pack on the growth of other indigenous pathogens is minimum. There is a less chance to grow a large number of aerobic microbes due to vacuum packing of samples. Handling procedure is a primary factor for the contamination. Frequently, same knives are used for loaning and steaking (cut fish parts for different sizes) during the export processing. The obtained samples for this study were processed in the same manner.

Hence, surface bacteria can contaminate with the internal flesh. Furthermore, the temperature has a strong effect on producing histamine (Jinadasa et al. 2015) and the temperature variation causes rapid increase in bacterial counts (Du et al. 2002). Fish storage temperature may change during the processing of fish before the samples were taken. Therefore, in the initial day of storage (day1), histamine may be present in a considerable amount. Total microbial count has reduced from day 7 to day 15 . It could be due to increasing histamine level and the development of anaerobic conditions under the vacuum pack. Initially, both anaerobic bacteria and aerobic bacteria present in the flesh and all bacteria do not produce histamine (Kim et al. 1999). Moreover, some bacteria need specific media and specific conditions to grow well (Kim et al. 2001). But in this study, we used a nutrient agar medium for all microbes grown in fish flesh. These could be the reasons for reduction in total plate count from day 7 to day 15 .

Histamine formation is also due to the time and temperature abuse of fish during handling. Normally freshly captured fish contain a very low amount of histamine since they are chilled immediately (Chen et al. 1989, Kung et al. 2017). Commercially acceptable fish usually contain less than $5 \mathrm{ppm}$ of histamine and rarely over 20 ppm. The average histamine levels in the commercial raw frozen YFT is $2 \mathrm{ppm}$.

Generally, good quality fish contain less than $10 \mathrm{ppm}$ of histamine concentration. Above 30 ppm histamine considered as significant deterioration and especially $50 \mathrm{ppm}$ or above is considered to be the evidence of definite decomposition of fish (Chen et al. 1989). 
L. H. D. Hansamali et al.

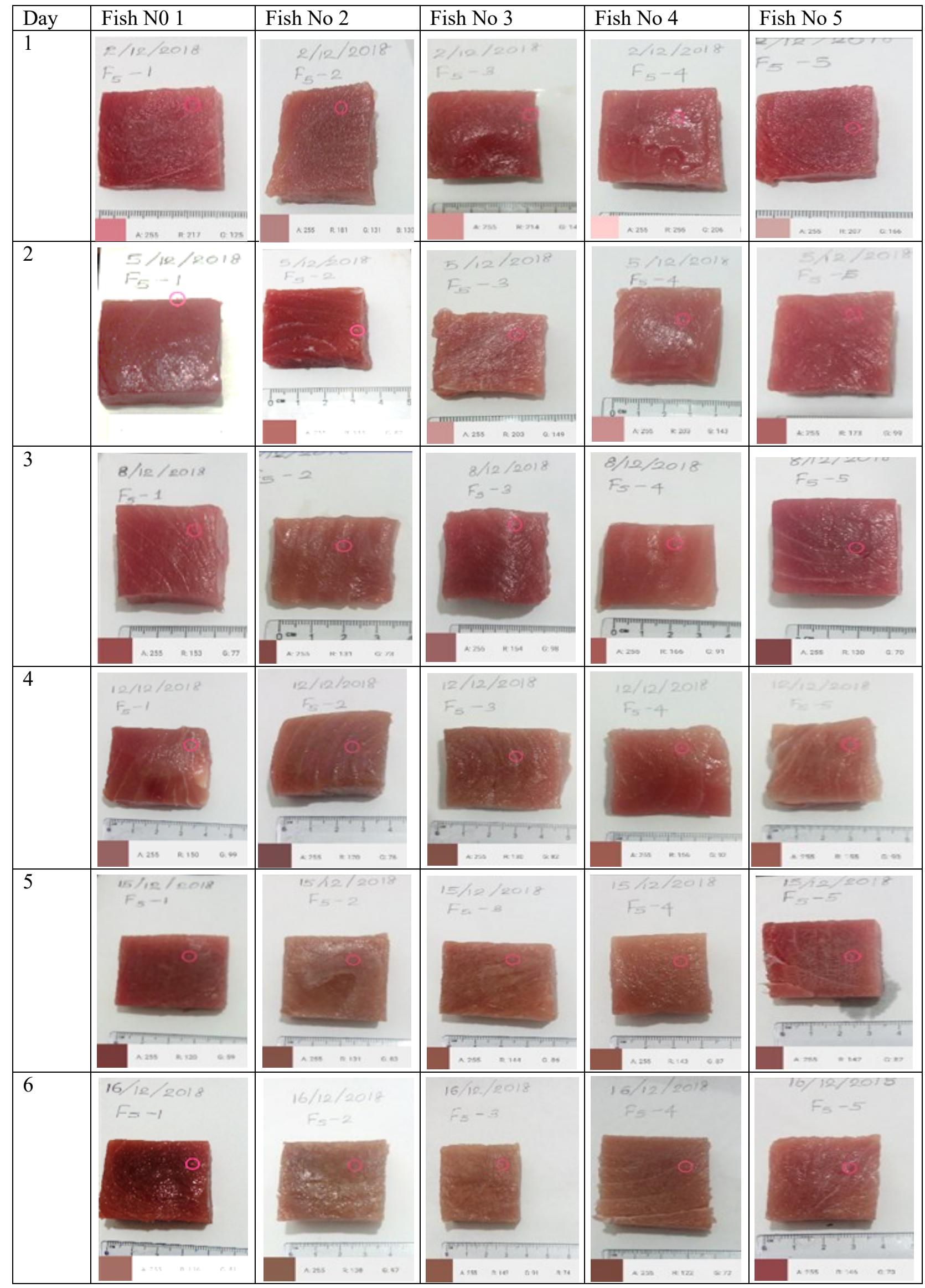

Fig 4 Change of YFT flesh colour within 15 days of storage at $0-2^{\circ} \mathrm{C}$ 
Tuna is a migratory species; hence the chemical composition of the body may depend on the location they live, the depth of the sea, salinity and the temperature. The body colour and flesh colour may also vary depending on such extrinsic factors. High histamine concentrations and high microbial counts were shown in day 1 of storage in some fish. The reason may be poor cooling conditions, poor handling, poor landing, and the poor postharvest knowledge of fishermen. Generally, fish with histidine is highly susceptible to produce histamine with a concentration at levels above $200 \mathrm{ppm}$, often above 500 ppm (Visciano et al. 2014). It can be severe, moderate, and mild with regard to the concentration of toxic histamine percentage. Therefore, poor postharvest handling may result in exceptionally high histamine levels. Also, this histidine concentration may vary with the season, sex, feeding and on the maturity stage of the fish (Chen et al. 1989).

\section{ACKNOWLEDGMENTS}

The authors extend their deepest gratitude to Mr. Gamini Pathirage (Production Director), and the other employees at Jay Sea Foods Processing (Pvt.) Ltd for the support given. Moreover, authors wish to thank the Department of Botany, and Centre for Marine Science and Technology, University of Sri Jayewardenepura, for the support in the laboratory analysis.

\section{REFERENCES}

Agustini, T.W., T. Suzuki, T.Hagiwara, S. Ishizaki, M. Tanaka, R. Takai. 2001. Change of $\mathrm{K}$ value and water state of yellowfin tuna Thunnus albacares meat stored in a wide temperature range $(20 \mathrm{C}$ to- $84 \mathrm{C})$. Fisheries Science 67(2): 306-313.

Baranowski, J., H. Frank, P. Brust, M. Chongsiriwatana, R. Premaratne. 1990. Decomposition and histamine content in Mahimahi (Coryphaena hippurus). Journal of Food Protection 53:217-222.

Chen, C.M., C.I. Wei, J.A. Koburger, M.R. Marshall. 1989. Comparison of four agar media for detection of histamine-producing bacteria in tuna. Journal of Food Protection 52(11): 808-813.

Du, W.X., C.M. Lin, A.T. Phu, J.A. Cornell, M.R. Marshall, C.I. Wei. 2002. Development of biogenic amines in yellowfin tuna (Thunnus albacares): effect of storage and correlation with decarboxylase-positive bacterial flora. Journal of Food Science 67(1): 292-301.

EU/EC. 2005. Commission Regulation (EC) No 2073/2005 on microbiological criteria for foodstuffs. Official Journal of the European Union 338: 1-26.

Guizani, N., M.A. Al-Busaidy, I.M. Al-Belushi, A. Mothershaw, M.S. Rahman. 2005. The effect of storage temperature on histamine production and the freshness of yellowfin tuna (Thunnus albacares). Food Research International 38(2): 215-222.

Gram, L, H.H. Huss. 1996. Microbiological spoilage of fish and fish products. International Journal of Food Microbiology 33(1):121-137.

Gray, J.I., E.A. Gomaa, D.J. Buckley. 1996. Oxidative quality and shelf life of meats. Meat Science 43: 111-123.

Jinadasa, B.K.K.K., C.K. Galhena, N.P.P. Liyanage. 2015. Histamine formation and the freshness of yellowfin tuna (Thunnus albacares) stored at different temperatures. Cogent Food \& Agriculture 1(1): 1028735.

Kim, S.H., H. An, R.J. Price. 1999. Histamine formation and bacterial spoilage of albacore harvested off the US Northwest coast. Journal of Food Science 64(2):340-343.

Kim, S.H., K.G. Field, M.T Morrissey, R.J. Price, C.I. Wei, H. An. 2001. Source and identification of histamine-producing bacteria from fresh and temperature-abused albacore. Journal of Food Protection 64(7): 1035-1044.

Kim, S.H., C.I. Wei, R.A. Clemens, H. An. 2005. Histamine accumulation in seafood and its control to prevent outbreaks of scrombroid poisoning. Journal of Aquatic Food Product Technology 13(4): 81-100.

Kung, H.F., Y.C. Lee, C.W. Lin, Y.R. Huang, C.A. Cheng, C.M. Lin, Y.H. Tsai. 2017. The effect of vacuum packaging on histamine changes of milkfish sticks at various storage temperatures. Journal of Food and Drug Analysis 25(4): 812-818.

Lehane, L. Olley, J. 2000. Histamine fish poisoning revisited. International Journal of Food Microbiology 58(1-2): 1-37.

Mateo, A., F. Soto, J.A. Villarejo, J. Roca-Dorda, F. De la Gandara, A. García. 2006. Quality analysis of tuna meat using an automated 
color inspection system. Aquacultural Engineering 35(1): 1-13.

Odrowaz, R. 2019. RGB colour picker Arcuilo. https://apkcombo.com/rgb-colorpicker/com.odrowaz.robert.rgb2

Olsen, S.J., L.C. MacKinon, L.S. Goulding, N.H. Bean, L. Slutsker. 2000. Surveillance for foodborne-disease outbreaks, United States. MMWR CDC Surveillance Summaries 49(SS01): 1-51.

Price, R.J., E.F. Melvin, J.W. Bell. 1991. Postmortem changes in chilled round, bled and dressed albacore. Journal of Food Science, 56(2):318-321.

Visciano, P., Schirone, M., Tofalo, R., Suzzi, G. 2014. Histamine poisoning and control measures in fish and fishery products. Frontiers in Microbiology 5:500.

Wei, C.I., Chen, C.M., Koburger, J.A., Otwell, W.S., Marshall, M.R. 1990. Bacterial growth and histamine production on vacuum packaged tuna. Journal of Food Science 55(1): 59-63. 